\title{
Pneumonia - A major clinical challenge
}

\author{
THOMAS J MARRIE, MD, FRCPC
}

$\mathrm{P}$ NEUMONIA IS AN INFECTION OF THE AIR SPACES OF THE lung. It is a significant cause of morbidity and mortality and represents a major diagnostic and therapeutic challenge.

The attack rates for pneumonia are highest at the extremes of age. The rate of pneumonia per $1000 \mathrm{popu}-$ lation ranges from $3 / 1000$ adults in England (1) to $12 / 1000$ in Seattle, Washington (2).

The mortality rate for community-acquired pneumonia requiring hospitalization ranges from 5.7 to $21 \%$ $(3,4)$. Such rates are meaningless unless there is a uniform admission policy or a pneumonia-specific severity of illness scoring system that will allow comparison of data from centre to centre. The mortality rate among patients primarily treated as outpatients is much lower $-1.2 \%$ (5).

After the physician has made a diagnosis of pneumonia, based on clinical and radiographic criteria, the next step is to make an etiological diagnosis. Many patients cannot produce a sputum sample for culture, or they are already receiving antibiotic therapy at the time of admission. Thus, empiric treatment is often necessary. To make the most appropriate antibiotic choice in this setting it is necessary to know the results of carefully designed and executed studies. In such studies the following criteria for the level of certainty of the etiologic diagnosis of pneumonia should be kept in mind (6).

\section{A. Definitive}

- Blood cultures yielding a pathogen

- Pleural fluid yielding a pathogen

- Bronchoalveolar lavage revealing Pneumocystis carinii

- Open-lung biopsies yielding a pathogen

- Isolation of Mycoplasma pneumoniae from respiratory tract samples or a fourfold rise in antibody titre

- Positive direct fluorescent antibody test for Legionella species plus an elevated Legionella titre

- A fourfold or greater rise in antibody titre for Chlamydia pneumoniae

\section{B. Presumptive}

- Heavy or moderate growth of a predominant bacterial pathogen on sputum culture

- Light growth of a pathogen in which the sputum Gram stain revealed a bacterium compatible with the culture results

- Bacterium isolated on multiple sputum cultures within three days of admission 
TABLE 1

Etiology of community-acquired pneumonia requiring hospitalization - North America

\begin{tabular}{lcc}
\hline & \multicolumn{2}{c}{ Study (reference) } \\
& Marrie et al (4) & Fang et al (6) \\
\hline Number of patients studied & 719 & 359 \\
Number (\%) patients with & $257(36)$ & $336(94)$ \\
sputum cultured & & \\
Time period of study & November 1, & July 1, 1986 to \\
& 1981 to & June 30,1987 \\
Number (\%) with & March 18, 1987 & \\
pneumonia of: & & \\
Unknown etiology & $340(47)$ & $118(32.9)$ \\
More than one etiology & $74(10.3)$ & $10(2.8)$ \\
Streptococcus pneumoniae & $61(8.5)$ & $39(10.9)$ \\
Aspiration & $52(7.2)$ & $12(3.3)$ \\
Mycoplasma pneumoniae & $40(5.6)$ & $7(2)$ \\
Influenza A & $40(5.6)$ & Not tested \\
Staphylococcus aureus & $29(4.0)$ & $12(3.3)$ \\
Haemophilus influenzae & $27(3.7)$ & $39(10.9)$ \\
Coxiella burnetii & $22(3.1)$ & Not tested \\
Aerobic Gram-negative & $22(3.1)$ & $21(5.9)$ \\
bacteria & & \\
Influenza B & $17(2.4)$ & Not tested \\
Pneumocystis carinii & $14(1.9)$ & $9(2.5)$ \\
Legionella species & $16(2.2)$ & $24(6.7)$ \\
Mycobacterium tuberculosis & $10(1.4)$ & $4(1.1)$ \\
Chlamydia pneumoniae & $18 / 301(6) *$ & $22(6.1)$ \\
Postobstructive & $13(1.8)$ & $19(5.3)$ \\
\hline
\end{tabular}

*Only 301 patients had serum samples tested for antibodies to $\mathrm{C}$ pneumoniae

- A single elevated titre of 1:320 to Legionella pneumophila by enzyme-linked immunosorbent assay (ELISA) or 1:512 or higher titre by indirect immunofluorescence assay

- C pneumoniae IgM antibody titre 1:32 or higher

\section{Unknown etiology}

- Normal flora on respiratory tract culture

- Light growth of multiple organisms on culture

- Cases not fulfilling any of the above conditions

Table 1 shows the results of two studies of community-acquired pneumonia requiring hospitalization performed in Pittsburgh, Pennsylvania (6) and Halifax (4) in the 1980s. Note that most of the patients in Pittsburgh had sputum cultures obtained while only $36 \%$ of the Halifax patients had such cultures. The etiology of the pneumonia was undetermined in $33 \%$ and $47 \%$ of the patients in the two studies. Streptococcus pneumoniae was the most common etiologic agent identified although it accounted for only $10.9 \%$ and $8.5 \%$ of the cases in the two studies, respectively. A wide variety of agents were found (Table 1). Legionella was more com-
TABLE 2

Etiology of blood culture positive pneumonia in two studies of community-acquired pneumonia requiring hospitalization

\begin{tabular}{lll}
\hline & \multicolumn{2}{c}{ Study (reference) } \\
& Marrie et al (4) & Fang et al (6) \\
\hline $\begin{array}{l}\text { Number (\%) of patients who } \\
\text { had blood cultures done }\end{array}$ & $539(75)$ & $314(89.5)$ \\
Number (\%) with positive & $48(8.9)$ & $28(8.9)$ \\
blood cultures & & \\
Number (\%) with indicated & & \\
microorganism in blood: & & $16(57)$ \\
Streptococcus pneumoniae & $28(58)$ & $4(14)$ \\
Staphylococcus aureus & $1(2)$ & $1(3.5)$ \\
Haemophilus influenzae & $2(4)$ & $2(7)$ \\
Streptococcus species & $8(16)$ & $1(3.5)$ \\
Legionella pneumophila & 0 & $1(3.5)$ \\
Actinomyces israelii & 0 & $1(3.5)$ \\
Pseudomonas aeruginosa & $1(2)$ & $1(3.5)$ \\
Serratia marcescens and & 0 & $1(3.5)$ \\
Acinetobacter & & 0 \\
calcoaceticus & & 0 \\
Bacteroides fragilis & $1(1)$ & 0 \\
Escherichia coli & $3(6)$ & 0 \\
Klebsiella pneumoniae & $2(4)$ & $1(3.5)$ \\
Neisseria meningitidis W135 & $1(1)$ & $1(1)$ \\
Salmonella montevideo & $1(1)$ & \\
Bifidobacterium species & $4(8)$ & \\
Polymicrobial & & \\
\hline & & \\
\hline
\end{tabular}

mon in Pittsburgh than in Halifax. In both centres $C$ pneumoniae accounted for $6 \%$ of the pneumonias. With the advent of the acquired immune deficiency syndrome (AIDS), $P$ carinii has become an important cause of community-acquired pneumonia (7). In these two studies it accounted for $2.5 \%$ and $1.9 \%$ of the cases, respectively. In the Pittsburgh study using the definitions previously outlined, 79 of the $210(37.6 \%)$ with an assigned etiology were classified as definitive and 131 $(62.4 \%)$ were classified as presumptive.

The results of blood cultures performed in the studies cited in Table 1 are presented in Table 2. Nine per cent of patients in both studies were bacteremic and the pneumococcus accounted for $58 \%$ of organisms isolated.

It seems as if the pneumococcus has decreased in importance as a cause of community-acquired pneumonia. In the 16 studies that Fang et al (6) reviewed $S$ pneumoniae was the main causal pathogen, accounting for 12 to $76 \%$ of the cases of pneumonia. In a study of 196 patients with community-acquired pneumonia requiring hospitalization in Copenhagen, $S$ pneumoniae accounted for $36 \%$ of the cases (8). However, the total number of infections due to $S$ pneumoniae would have been $70 \%$ if the diagnosis was based on one positive serological test for $S$ pneumoniae (8).

Since many patients with community-acquired 
pneumonia are treated as outpatients (9), it is important to know the cause of pneumonia in this group of patients. Unfortunately, such patients have been inadequately studied. Three studies $(5,10$, unpublished data) involving mostly outpatients with community-acquired pneumonia are summarized in Table 3.

There are several subsets of the general population in whom the rank order of the etiology of pneumonia is likely to be different from what has just been described for the group of patients with community-acquired pneumonia as a whole. The subset of patients requiring admission to an intensive care unit for treatment of their pneumonia has been defined in a series of studies (11-14). The results of these studies are shown in Table 4; S pneumoniae, L pneumophila, M pneumoniae, aerobic Gram-negative bacilli, viruses and Staphylococcus aureus are found most commonly. Even in this setting a significant percentage of the cases of pneumonia are of unknown etiology.

Community-acquired pneumonia in the elderly occurs in two settings - at home and in a nursing home. Nursing home-acquired pneumonia accounts for up to $18 \%$ of all cases of community-acquired pneumonia requiring admission to hospital (4). The mortality rate among this group of patients is high $-40 \%$ in our study (4). When we compared nursing home-acquired pneumonia with age and marked patients with communityacquired pneumonia, we found that aspiration pneumonia and pneumonia of unknown etiology were significantly more common among patients with nursing home-acquired pneumonia (4).

The major problem when dealing with this group of patients is to distinguish colonization from infection. In one study $23 \%$ of nursing home patients had colonization of the oropharynx with aerobic Gram-negative bacilli (15). In a study by Carr et al (16) involving 127
TABLE 3

Etiology of community-acquired pneumonia among patients who were not usually admitted to hospital

\begin{tabular}{|c|c|c|c|}
\hline & \multicolumn{3}{|c|}{ Słudy (reference) } \\
\hline & Erard (5) & $\begin{array}{l}\text { Woodhead } \\
\text { (10) }\end{array}$ & Marrie* \\
\hline $\begin{array}{l}\text { Number of patients } \\
\text { studied }\end{array}$ & 161 & 236 & 75 \\
\hline Location of study & Switzerland & $\begin{array}{l}\text { United } \\
\text { Kingdom }\end{array}$ & $\begin{array}{l}\text { Nova } \\
\text { Scotia }\end{array}$ \\
\hline $\begin{array}{l}\text { Number (\%) } \\
\text { hospitalized }\end{array}$ & $14(8.7)$ & $55(22)$ & $26(35)$ \\
\hline Number (\%) died & $2(1.2)$ & $7(3)$ & $3(4)$ \\
\hline \multicolumn{4}{|l|}{$\begin{array}{l}\text { Number (\%) with } \\
\text { pneumonia of: }\end{array}$} \\
\hline Unknown etiology & $76(47)$ & $107(45)$ & $43(57)$ \\
\hline $\begin{array}{l}\text { Streptococcus } \\
\text { pneumoniae }\end{array}$ & $17(10.5)$ & $83(36)$ & - \\
\hline Haemophilus species & $3(1.8)$ & $24(10)$ & - \\
\hline Moraxella catarrhalis & $2(1.2)$ & - & - \\
\hline Streptococcus species & $1(0.6)$ & - & - \\
\hline Legionella species & $3(1.8)$ & $1(0.5)$ & $2(3)$ \\
\hline Chlamydia & $9(5.5)$ & $3(1)$ & $1^{\dagger}$ \\
\hline $\begin{array}{l}\text { Mycoplasma } \\
\text { pneumoniae }\end{array}$ & $28(17.3)$ & $3(1)$ & $22(29)$ \\
\hline Coxiella burnetii & $3(1.8)$ & - & $2(3)$ \\
\hline Influenza viruses & $19(11.8)$ & $20(8.5)$ & $5(7)$ \\
\hline $\begin{array}{l}\text { Other respiratory } \\
\text { viruses }\end{array}$ & $7(4.3)$ & $10(4.2)$ & - \\
\hline Escherichia coli & - & $2(1)$ & - \\
\hline $\begin{array}{l}\text { Staphylococcus } \\
\text { aureus }\end{array}$ & - & $2(1)$ & - \\
\hline Proteus mirabilis & - & $1(0.5)$ & - \\
\hline Actinomyces israelii & - & $1(0.5)$ & - \\
\hline $\begin{array}{l}\text { Mycobacterium } \\
\text { tuberculosis }\end{array}$ & - & $3(1)$ & - \\
\hline Adenovirus & - & - & $2(3)$ \\
\hline
\end{tabular}

"Unpublished data; ${ }^{\text {Only }} 19$ patients tested for antibodies to this agent

\section{TABLE 4}

Etiology of community-acquired pneumonia requiring admission to intensive care

\begin{tabular}{|c|c|c|c|c|}
\hline & \multicolumn{4}{|c|}{ Słudy (reference) } \\
\hline & British Thoracic Society (11) & Torres (12) & Pachon (13) & Ortquist (14) \\
\hline Number of patients studied & 60 & 92 & 67 & 53 \\
\hline Mean age (years) & 54 & 53 & 56.8 & 52 \\
\hline Number (\%) died & $29(48)$ & $18(20)$ & $14(21)$ & $13(25)$ \\
\hline \multicolumn{5}{|l|}{$\begin{array}{l}\text { *Number (\%) with pneumonia } \\
\text { due to: }\end{array}$} \\
\hline Haemophilus influenzae & $7(12)$ & - & - & - \\
\hline Legionella pneumophila & $7(12)$ & $13(14)$ & $7(10)$ & - \\
\hline Mycoplasma pneumoniae & $4(7)$ & $6(7)$ & - & $3(5)$ \\
\hline Influenza virus & $3(5)$ & - & - & $2(4)$ \\
\hline Staphylococcus aureus & $2(3)$ & 1 & - & $2(4)$ \\
\hline
\end{tabular}

"The six most common causes are listed 
TABLE 5

Etiology of pneumonia in the elderly

\begin{tabular}{lc}
\hline & Study: Venkatesan (17) \\
\hline Number of patients studied & 73 \\
Location of study & Nottingham, UK \\
Median age (years) & 79 \\
Number (\%) died & $24(33)$ \\
Sputum cultured & $62(84)$ \\
Number (\%) with pneumonia of: & \\
Unknown etiology & $42(57)$ \\
Streptococcus pneumoniae & $23(30)$ \\
Haemophilus influenzae & $5(7)$ \\
Legionella pneumophila & $2(3)$ \\
Influenza B virus & $5(7)$ \\
Respiratory syncytial virus & $1(1.4)$ \\
\hline
\end{tabular}

\section{TABLE 6}

Clues to the etiology of community-acquired pneumonia from history

\begin{tabular}{|c|c|}
\hline Microorganism & Clue \\
\hline $\begin{array}{l}\text { Legionella } \\
\text { pneumophila }\end{array}$ & $\begin{array}{l}\text { Exposure to contaminated water } \\
\text { source: air conditioning, cooling tower, } \\
\text { grocery shop mist machine }\end{array}$ \\
\hline $\begin{array}{l}\text { Streptococcus } \\
\text { pneumoniae }\end{array}$ & $\begin{array}{l}\text { Shelter for homeless men, jails, South } \\
\text { African miners, army barracks }\end{array}$ \\
\hline $\begin{array}{l}\text { Mycoplasma } \\
\text { pneumoniae }\end{array}$ & Infected family member \\
\hline Coxiella burnetii & $\begin{array}{l}\text { Exposure to infected parturient cats, } \\
\text { sheep, cattle, goats }\end{array}$ \\
\hline $\begin{array}{l}\text { Mycobacterium } \\
\text { tuberculosis }\end{array}$ & $\begin{array}{l}\text { Exposure to an infected person } \\
\text { (especially one with cavitary disease in } \\
\text { a closed setting) - nursing home, } \\
\text { shelter for the homeless, HIV-positive } \\
\text { patient }\end{array}$ \\
\hline $\begin{array}{l}\text { Histoplasma } \\
\text { capsulatum }\end{array}$ & $\begin{array}{l}\text { Exposure to contaminated bat caves, } \\
\text { excavation in endemic areas, fallen } \\
\text { trees in endemic areas }\end{array}$ \\
\hline $\begin{array}{l}\text { Coccidioides } \\
\text { immitis }\end{array}$ & $\begin{array}{l}\text { Following a wind storm in an endemic } \\
\text { area }\end{array}$ \\
\hline
\end{tabular}

elderly patients with lower respiratory tract infection requiring admission to hospital, 79 patients (62\%) had pneumonia. Venkatesan and co-workers (17) studied 73 patients 65 years or older with pneumonia (they excluded patients with severe chronic illness in whom pneumonia was an expected terminal event). However, even then the mortality rate was very high - 33\%. Table 5 gives the causes of pneumonia in this group of patients. S pneumoniae was the most commonly isolated pathogen. No etiological agent was identified for $57 \%$ of the patients.

Patients who have AIDS frequently develop pneumonia and account for a significant population of all patients with community-acquired pneumonia. $P$ carinii still accounts for a substantial percentage of all cases of pneumonia in this group although now it represents only about $27 \%$ of the pneumonias (18). The incidence of pneumococcal pneumonia among patients with AIDS is 5.5 to 17.5 fold higher than that in the general population (19). A wide variety of pathogens can cause pneumonia in this immunosuppressed population (20).

Chronic obstructive pulmonary disease (COPD) is a frequent co-morbid condition among patients with community-acquired pneumonia; $32 \%$ of the Halifax patients (4) and $53 \%$ of the patients admitted to the Veterans Administration hospital in Pittsburgh with pneumonia had this condition (6). Twenty-two per cent of the patients with pneumonia at two other Pittsburgh hospitals had COPD (6). Overall $31.4 \%$ of the patients in the Pittsburgh study had COPD. Despite the frequent co-existence of these two conditions, studies delineating this subgroup of pneumonia patients are almost nonexistent. Indeed Griffith and Mazurek (21) state "it currently is difficult to establish a clear picture of pneumonia in COPD, including incidence, cause, optimal diagnostic procedures, and treatment". These authors had the impression that there had been a relative decline in importance of pneumococcal disease, more frequent isolation of Gram-negative rods (particularly Pseudomonas species) and the emergence of 'new' pathogens such as Moraxella catarrhalis (21).

In general terms the approach to the patient with pneumonia should include a careful search for clues to the etiology from the history (Table 6), the physical examination, radiographic features and examination of a Gram stain of the sputum. Often, however, one has to initiate empiric therapy. The best approach then is to tailor treatment to the severity of illness of the patient. If the patient can be treated as an outpatient, a macrolide is probably the best choice. If the patient requires admission to an intensive care unit triple therapy should be used - erythromycin, rifampin and a third generation cephalosporin with activity against Pseudomonas aeruginosa. This regimen can be modified as soon as the results of the diagnostic studies are available.

\section{REFERENCES}

1. MacFarlane J. Community-acquired pneumonia. Br J Dis Chest 1987;81:116-8.

2. Foy HM, Cooney MK, Allan I, et al. Rates of pneumonia during influenza epidemics in Seattle, 1964 to 1975. JAMA 1979:24:253-8.

3. British Thoracic Society. Community-acquired pneumonia in adults in British hospitals in 1982-1983: A survey of etiology, mortality, prognostic factors and outcome. Quart J Med 1987;62:195-220.

4. Marrie TJ, Durant H, Yates L. Community-acquired pneumonia requiring hospitalization: 5-year prospective study. Rev Infect Dis 1989;11:586-99.

5. Erard PH, Moser F, Wenger A, Saghafi L, Bille J, Francioli $\mathrm{P}$, and a group of practitioners at Neuchatel. Prospective study on community-acquired pneumonia diagnosed and followed up by private practitioners. Abstracts of the 1991 Interscience Conference on Antimicrobial Agents and Chemotherapy. Am Soc Microbial 1991;108. (Abst 56)

6. Fang GD, Fine M, Orloff J, et al. New and emerging 
etiologies for community-acquired pneumonia with implications for therapy. A prospective multicenter study of 359 cases. Medicine 1990;69:307-16.

7. Miller RF, Mitchell DM. Pneumocystis carinii pneumonia. Thorax 1992:47:305-14.

8. Burman IA, Trollfors B, Andersson B, et al. Diagnosis of pneumonia by cultures, bacterial and viral antigen detection tests, and serology with special reference to antibodies against pneumococcal antigens. J Infect Dis 1991;163:1087-93.

9. Foy HM, Wentworth B, Kenny GE, Kloeck JM, Grayston JT. Pneumococcal isolations from patients with pneumonia and control subjects in a prepaid medical care group. Am Rev Respir Dis 1975;111:595-603.

10. Woodhead MA, MacFarlane JT, McCracken JS, Rose DH, Finch RG. Prospective study of the aetiology and outcome of pneumonia in the community. Lancet 1987;ii:671-4.

11. British Thoracic Society Research Committee. The aetiology, management and outcome of severe community acquired pneumonia on the intensive care unit. Respir Med 1992;86:7-13.

12. Torres A, Serra-Battles J, Ferrer A, et al. Severe community-acquired pneumonia. Epidemiology and prognostic factors. Am Rev Respir Dis 1991;144:312-8.

13. Pachon J, Padros MD, Capote F, Cuello JA, Garnacho J, Verano A. Severe community-acquired pneumonia. Etiology, prognosis and treatment. Am Rev Respir Dis 1990;142:369-73.
14. Ortquist A, Sterner G, Nilsson JA. Severe community-acquired pneumonia: Factors influencing need of intensive care treatment and prognosis. Scand $J$ Infect Dis 1985:17:371-86.

15. Valenti WM, Trudell RG, Bentley DW. Factors predisposing to oropharyngeal colonization with Gramnegative bacilli in the aged. $\mathrm{N}$ Engl $\mathrm{J}$ Med 1978;298:1108-11.

16. Carr B, Walsh JB, Coakley D, Mulvihill E, Keane C. Prospective hospital study of community-acquired lower respiratory tract infection in the elderly. Respir Med 1991;85:185-7.

17. Venkatesan P, Gladman J, Macfarlane JT, et al. A hospital study of community-acquired pneumonia in the elderly. Thorax 1990;45:254-8.

18. Willocks L, Cowan F, Brettle RP, Emmanuel FXS, Flegg PJ, Burns S. The spectrum of chest infections in HIV positive patients in Edinburgh. J Infect 1992;24:37-42.

19. Janoff EN, Breiman RF, Daley CL, Hopewell PC. Pneumococcal disease during HIV infection. Epidemiologic, clinical, and immunologic perspectives. Ann Intern Med 1992;117:314-24.

20. Murray JF, Mills J. Pulmonary infectious complications of human immunodeficiency virus infection. Am Rev Respir Dis 1990;141:1356-72.

21. Griffith DE, Mazurek GH. Pneumonia in chronic obstructive lung disease. Infect Dis Clin N Am 1991;5:467-84. 


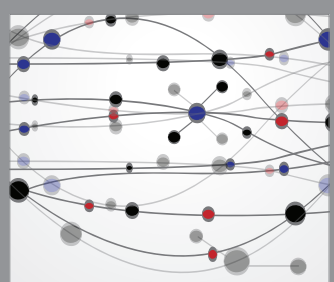

The Scientific World Journal
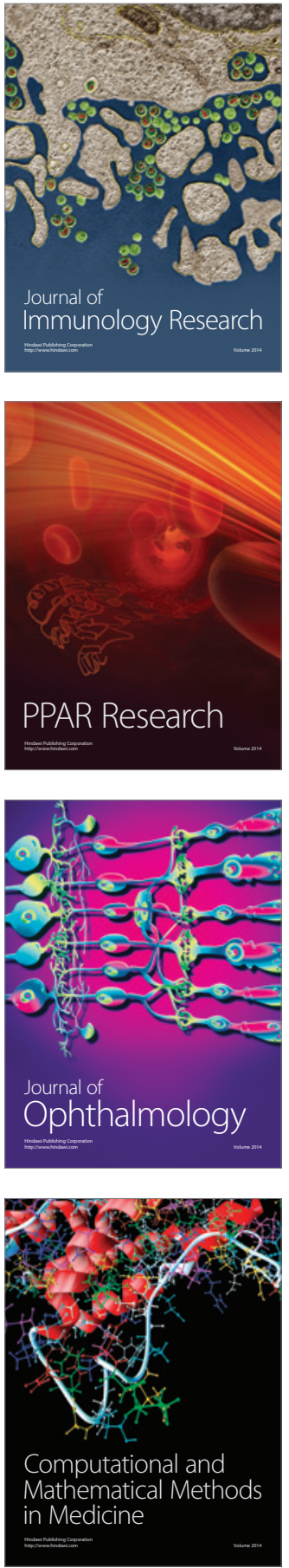

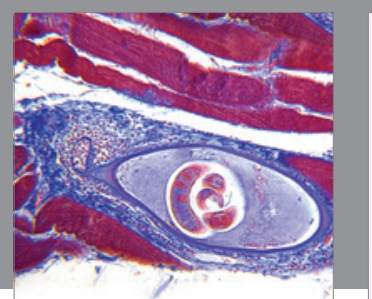

Gastroenterology Research and Practice

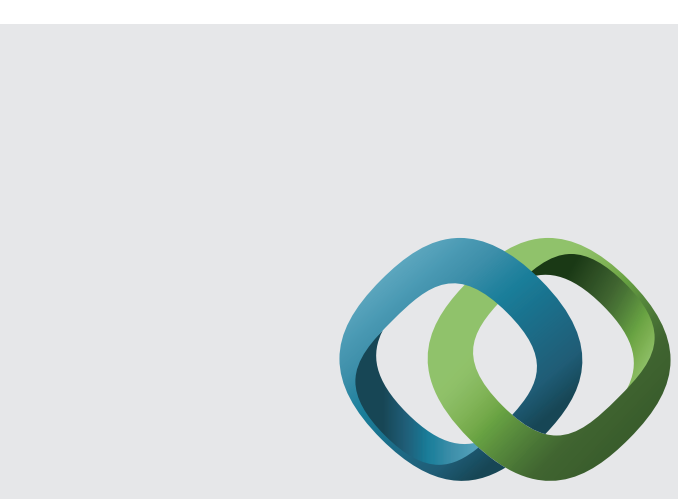

\section{Hindawi}

Submit your manuscripts at

http://www.hindawi.com
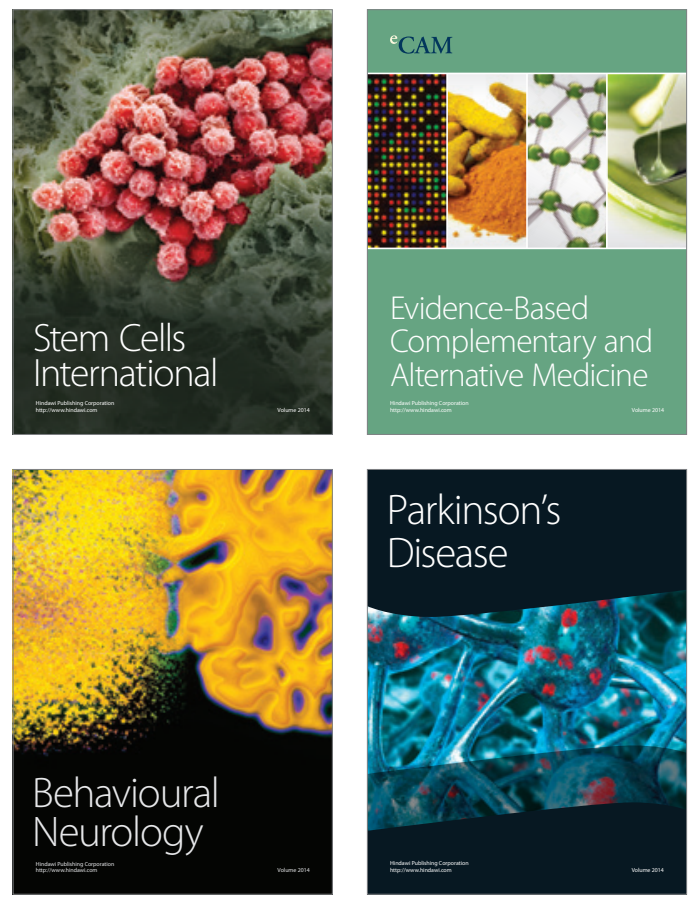
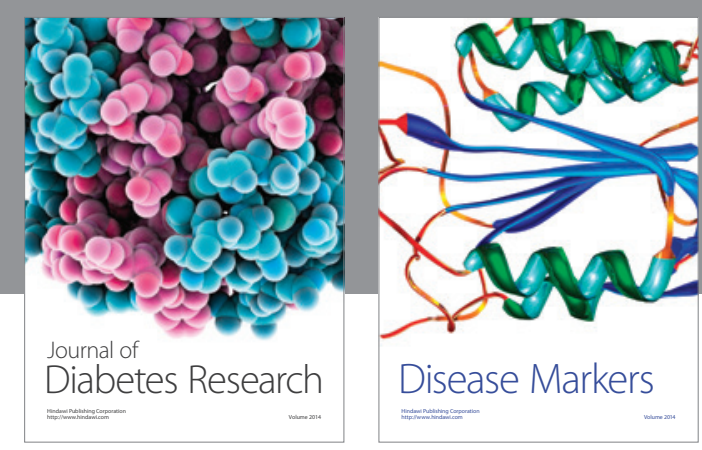

Disease Markers
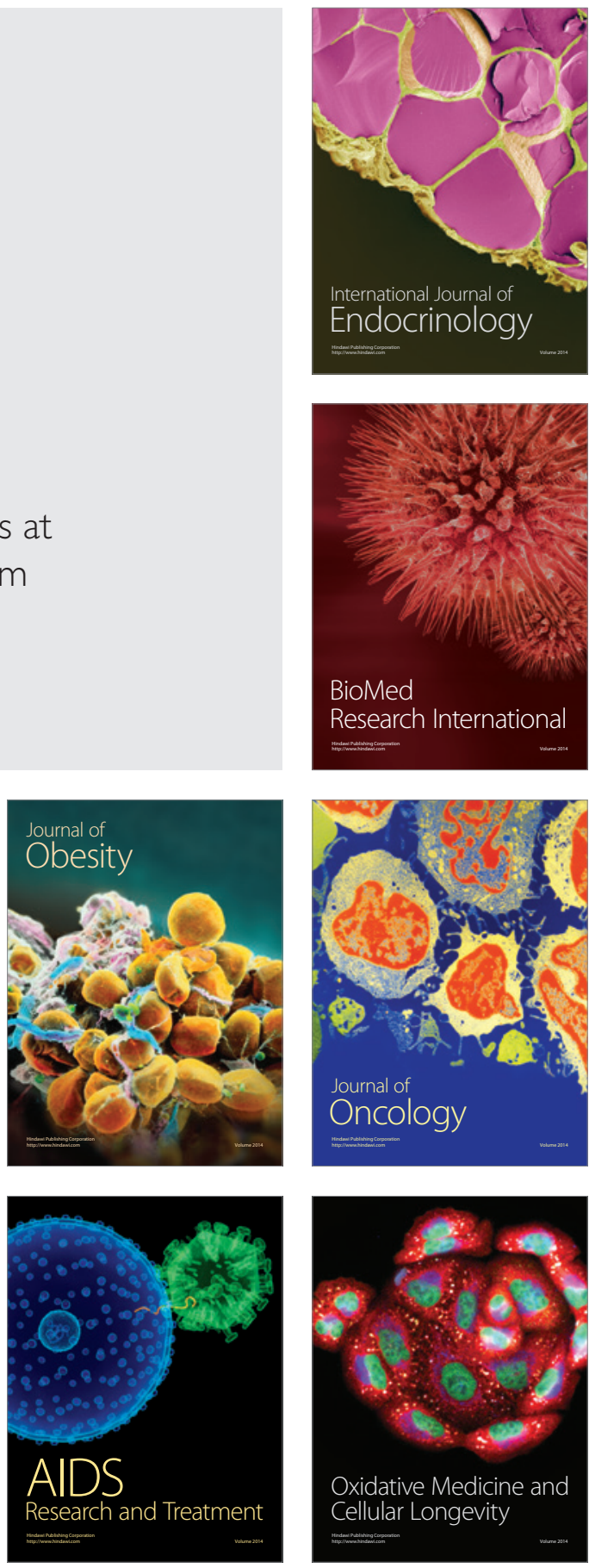